\title{
A reorganização e a fluidez do uso da mão de obra indígena no Grão-Pará: segunda metade do século XVIII (1750-1765)
}

\author{
The reorganization and fluidity of the use of indigenous labor \\ in Grão-Pará: second half of the 18th century (1750-1765)
}

\author{
Décio de Alencar Guzmán ${ }^{1}$ \\ Leonardo Raiol Junior ${ }^{1}$
}

DOI: http://dx.doi.org/ 10.20435/tellus.v19i39.595

Resumo: O presente trabalho visa discutir a respeito do contexto histórico amazônico ao qual abarca uma série de nuances, uma delas se refere a promulgação das leis que regulavam a liberdade indígena, das quais verificam a Lei de Liberdade dos Índios, publicada em 1755, e a Lei do Diretório dos Índios, decretada dois anos depois. Além disso, buscou-se acentuar de modo contundente a figura dos índios em algumas vilas ou aldeias que fizeram parte da Capitania do Grão-Pará, no período que compreende os anos de 1750 a 1765. Em suma, o objetivo foi refletir não somente a figura dos índios como sujeitos históricos nesse contexto colonial e de como eles estavam inseridos em uma dinâmica de trabalho que envolvia diferentes agentes coloniais, mas também, procurou-se analisar as estratégias, as mobilidades e as articulações indígenas.

Palavras-chave: trabalho indígena; período pombalino; Amazônia Colonial; Capitania do Grão-Pará; século XVIII.

\begin{abstract}
The present work aims at discussing the historical context of the Amazon, which includes a series of nuances, one of which refers to the enactment of the laws that regulate indigenous liberty, from which the Indian Freedom Law published in 1755 and the Law of the Directory of the Indians, decreed two years later. In addition, it was sought to emphasize in a striking manner the figure of the Indians in some towns or villages that were part of the Captaincy of the Grand-Pará, in the period that comprises the years of 1750 to 1765. In short, the objective was to reflect not only the figure of the Indians as historical subjects in this colonial context and of how they were inserted in a work dynamic that involved different colonial agents, but also, it was tried to analyze the strategies, the mobilities and the articulations Indians.
\end{abstract}

Keywords: indigenous labor; period of Pombal; Amazônia Colonial; Captaincy of Grão-Pará; 18th century.

1 Universidade Federal do Pará (UFPA), Belém, Pará, Brasil. 


\section{INTRODUÇÃO}

As inflexões que serão discutidas neste trabalho se referem ao contexto histórico no qual abarca uma série de nuances, entre as quais estão a promulgação das leis que regulavam a liberdade indígena, tais como a Lei de Liberdade dos Índios, publicada em 1755, e a Lei do Diretório dos Índios, decretada dois anos depois. Além disso, buscou-se acentuar de modo contundente a figura dos índios em algumas vilas e aldeias que fizeram parte das delimitações territoriais da Província do Grão-Pará, no período em que envolve os anos de 1750 a 1765.

Com a apropriação do aporte teórico e, principalmente, da inflexão feita mediante às diferentes fontes históricas, além de terem auxiliado na metodologia e na construção do trabalho, esses instrumentos foram imprescindíveis na sustentação dos argumentos e na própria narrativa histórica. Análises estas que possibilitaram refletir mediante a um quadro amplo da sociedade colonial, onde as relações entre sujeitos, como colonos, missionários, autoridades coloniais e grupos indígenas estavam inseridos em uma rede complexa que envolve relações por meio de trocas, negociações ou sublevações.

A reflexão está dividida em três pontos, entre os quais estão assinalados, a princípio, uma dimensão do contexto histórico da colônia, sobretudo, a respeito da política, da economia, do campo jurídico e de aspectos que abarcam o cenário da Província do Grão-Pará, no contexto de 1750 a 1765. No que se refere ao segundo ponto, buscou-se analisar o papel das leis indigenistas que, por sua vez foram promulgadas a partir da segunda metade do século XVIII, cujo principal objetivo era regular a mão de obra indígena. No âmbito dessa questão, situa-se o trabalho indígena que ironicamente passava pelo processo de regulação e de proibição do cativeiro dos índios, não obstante, as nações indígenas ainda eram subjugadas a escravidão nos sertões amazônicos.

Por conseguinte, no último ponto, a reflexão envereda pelas ações indígenas, isto é, como os índios agiam, articulavam-se e mobilizavam-se para subverter qualquer forma de sujeição ao seu favor? O intuito foi compreender as mais diversas maneiras de estratégias indígenas, entre as mais proeminentes estavam as deserções para os sertões, uma das maneiras que os índios encontravam para burlar as dominações feitas por diferentes agentes coloniais. 


\section{DISPUTAS, PODER E CONTRADIÇÕES: A POLÍTICA INDIGENISTA NO GRÃO-PARÁ (1750-1757)}

O contexto que precede a implantação do Diretório dos Índios, em 1757, revela-nos um quadro permeado de disputas, contradições e negociações. Os anos entre 1750 e 1757, é o momento ao qual estavam mais evidentes as políticas pombalinas e o quão as relações dos agentes coloniais estavam entrelaçadas num processo complexo, como destaca Coelho (2007, p. 31). É possível perceber, nas fontes documentais, uma série de evidências a respeito da implementação dessas políticas e da própria situação social que se encontravam colonos e os agentes lusitanos.

Em meio a essa rede, houve tentativas profundas de incorporação dos indígenas nas atividades da administração colonial, com o processo de "transformação dos ameríndios em vassalos" conforme ressalta Domingues (2000, p. 38). Essa transformação perpassa a ideia da igualdade social e jurídica que os grupos indígenas teriam em relação aos colonos portugueses. Além disso, a mão de obra desses ameríndios era de suma importância para a consolidação do Projeto Lusitano². Outros aspectos que estão relacionados a essas transformações, correspondem aos processos civilizatórios que incidiam diretamente nos grupos indígenas da colônia. Para que isto se efetivasse, era necessário o aprendizado obrigatório da língua portuguesa. Também, eles teriam a autorização para se casar com os não índios. Por fim, o trabalho indígena, teria uma parcela fundamental na execução das expedições de demarcações de limites para a efetiva ocupação territorial, assinala Garcia (2007).

As medidas encaminhadas a Mendonça Furtado, compreendem de certa maneira uma incongruência, pois as instruções que chegaram em suas mãos buscavam fomentar a liberdade dos índios, porém, como a mão de obra indígena era

2 Projeto este que visava não somente o fortalecimento da Coroa portuguesa, mas a sua expansão na colônia, isto é, no século XVIII, Portugal tinha pretensões de fortalecer o poder Estado e reformar a política econômica e social do país, visto que ainda estava aquém das outras nações europeias. Na colônia, na segunda metade do século XVIII, o Estado do Grão-Pará e Maranhão, foi alvo dessas ditas transformações que, por sua vez ficaram mais conhecidas como reformas pombalinas. As reformas vieram na implantação de Companhias de Comércio, na educação pública que substituía a dos jesuítas e consolidava a autoridade do Estado português em detrimento da autoridade eclesiástica das ordens religiosas. Ver: Maxwell (1996) e Villalta (1999). 
imprescindível para a economia da região, essas medidas não foram colocadas logo em prática, uma vez que elas esbarravam simplesmente numa questão ainda muito comum: o uso da mão de obra indígena nos mais diversos setores econômicos da região: na agricultura, na busca das drogas do sertão, nos engenhos, nas construções de canoas e nas demarcações das fronteiras. Portanto, a regulação da liberdade indígena foi um processo que se consolidava paulatinamente.

No tocante à liberdade dos índios, uma das diretrizes das políticas pombalinas foi retratada por meio de cartas entre Mendonça Furtado e o seu irmão Sebastião José. Em uma delas, Furtado relata a situação do índio Manuel, da aldeia de Uricuru, onde requereu autorização para viver numa localidade longe de onde habitava, pois já tinha cerca de 60 anos de idade, com o intuito de viver a "seu gosto". No entanto, quando Mendonça Furtado examinou a petição do índio Manuel junto ao Pe. Júlio Pereira, responsável pela aldeia, este ficou enfurecido e desqualificou o dito índio, dizendo-Ihe que era um "magaço" e pertencia à aldeia Uricuru. Mendonça Furtado relatou que ficou confuso por não saber lidar com a liberdade indígena e ao mesmo tempo consternado com a situação em que tal índio estava, pois com tamanha idade não merecia continuar trabalhando ${ }^{3}$.

No que se refere ao uso da mão de obra indígena, ela se desdobra em duas vertentes, certamente de modo genérico, mas que nos fazem refletir sobre a sua utilização. Sobretudo, na dinâmica colonial são evidentes duas categorias: a primeira, os índios que eram legitimamente escravizados, ora eles eram prisioneiros a partir das guerras justas, ora eram aprisionados e obtidos por meio dos resgates, assinala Farage (1991, p. 28). Além disso, teremos a figura dos índios livres que, por sua vez, estavam na condição de aldeados e aliados, como expõe Perrone Moisés (1992, p. 117-8).

As guerras justas se caracterizaram na colônia, a partir de dois pontos de vista: a primeira se refere às incursões de grupos indígenas em algum acampamento de portugueses, os índios que fossem presos nesses tipos de ações eram legitimamente escravizados; a segunda maneira era o ataque iminente de

3 1a Carta, datada em 21 de novembro de 1751, enviada por Mendonça Furtado ao seu irmão Sebastião José de Carvalho e Melo, entre os assuntos tratados na correspondência estão os limites fronteiriços do Estado do Grão-Pará e Maranhão e as relações entre os Regulares da Companhia de Jesus com os índios. Ver: Mendonça (2005, tomo I, p. 109-26). 
indígenas, isto é, à medida em que esse ataque fosse surpreendido pelos colonos portugueses, os índios capturados eram levados à condição de escravos. No que diz respeito ao resgate, tal prática era legítima em algumas circunstâncias, sobretudo quando a captura dos prisioneiros ou escravos, geralmente grupos de índios inimigos, era realizada pelos índios aliados à coroa portuguesa, conforme salienta Farage (1991, p. 29).

Os descimentos eram práticas comumente incentivadas por religiosos e governadores, com a finalidade de deslocar um considerável número de grupos indígenas para ocupar as povoações. Nos aldeamentos, os índios poderiam estar na condição de homens "livres", de modo que em determinadas situações poderiam até receber salários pelos trabalhos efetuados nesses aldeamentos. Além disso, Perrone Moisés (1992, p. 117-8) acentua que conforme as relações de confiança fossem aumentando entre os índios e os religiosos, os indígenas poderiam ser tratados como aliados ao projeto colonial. No entanto, a configuração das relações sociais nesses aldeamentos é complexa, pois nem sempre os índios se habituavam aos tratamentos recebidos pelos padres, e quando os maus tratos prevaleciam, as fugas e as mais diversas formas de resistência ficavam mais evidentes.

Nesses aldeamentos, a administração ficava a cargo dos missionários. Isso ficou estabelecido desde a Lei de 21 de dezembro de 1686, com a instalação do "Regimento das Missões do Estado do Maranhão e Grão-Pará", como salienta Mello (2007, p. 209). Sobre essa questão, ficou definida a responsabilidade da administração dos índios aldeados, pelos missionários, porém, o controle dos religiosos foi muito além. Estes, por sua vez, ficaram também incumbidos de governar tanto a dimensão espiritual, como a temporal desses aldeamentos. Ou seja, os missionários, neste momento, foram os responsáveis direto em descer grupos indígenas para os aldeamentos, proporcionando assim, um aumento significativo no número de índios nesses aldeamentos. O propósito disso foi, principalmente, a preocupação com a defesa do Estado e a utilização da mão de obra indígena, além da questão missionária, que era um dos objetivos fundantes das ordens religiosas.

Os desdobramentos dessa questão ficaram mais evidentes com a implementação das políticas pombalinas, cujas ações dos missionários ficaram mais restritas, o controle passaria para às mãos do próprio Estado. Sob a influência dos ideais iluministas, um dos objetivos das políticas lusitanas foi secularizar as ações 
governativas: distinguir de forma definitiva as funções do Estado e as funções da Igreja. Mendonça Furtado expôs sua preocupação numa carta encaminhada ao seu irmão, em que se refere ao "grande poder dos Regulares neste Estado". Isso, segundo ele, "causaria ruína à administração".

Nessa carta, Furtado ressalta que a petição do Principal da Aldeia de Piraviri, no rio Xingu, remete a uma segunda queixa sobre o missionário daquela aldeia, o padre jesuíta João de Souza, pois os índios não confiavam nenhum pouco nas atitudes dele e, por isso, pediam que fosse feita a mudança do tal missionário. Entretanto, quando Mendonça Furtado foi então pedir que o Vice Provincial da Companhia tomasse providências, a respeito da situação, esta autoridade da Companhia nada realizou em prol do pedido. Logo, tal atitude demonstrou o quão os religiosos ainda tinham a autonomia chegando ao ponto de não cumprir uma solicitação do Governador do Estado4.

Em outra carta, Mendonça Furtado alertou o seu irmão sobre a "dissimulação" e a "persuasão" que os padres da Companhia de Jesus praticavam em relação aos índios. Nessa carta, Furtado relatou que havia diversos serviços para se fazer, tais como descarregar as naus e o trabalho na construção das canoas, pois para estes serviços era indispensável certa quantidade de índios que, por sua vez foram direcionados para tais trabalhos. Assim se fez nos primeiros dias, todos os índios executaram os serviços. Todavia, com o passar dos dias, menos índios tinha no local, pouco a pouco foram fugindo.

Vendo a situação, Furtado foi ao Colégio Santo Alexandre, disse ao padre Luís de Oliveira, Procurador Geral das Missões, que aquelas deserções não passavam de uma "má instrução" que os padres tinham feito com aqueles índios e que precisava da obediência deles. Contudo, o padre lhe respondeu que tinha feito "boas práticas", mas que não havia solução para tanta desobediência 5 .

4 6a Carta, datada em 29 de dezembro de 1751, cujo conteúdo enfatiza o poder dos Jesuítas na região e sobre a situação miserável no qual os povos indígenas se encontravam. Ver: Mendonça (2005, tomo I, p. 203-9).

5 43ํㅡ Carta, de 18 de outubro de 1753, esta correspondência faz referência às deserções indígenas, principalmente, no tocante a Feitoria das Canoas, a fuga de carpinteiros índios e os mestres do estaleiro desertavam com assídua frequência, sendo que a grande maioria desses índios que fugiam eram provenientes de três grandes aldeias: Guaricuru, Arucará (Portel) e Araticu, aldeias estas que estavam sob a administração dos jesuítas. Ver: Mendonça (2005, tomo I, p. 520-3). 
No que se refere a essas duas cartas, é possível apreendermos mediante a dois pontos de vista. O primeiro, remetem as relações que já estavam deterioradas entre o Estado e os religiosos. Mendonça Furtado, como agente administrativo e na sua "insistência" em colocar em prática as instruções régias que lhes foram passadas. Os jesuítas e missionários em geral eram vistos como uma ameaça, posto que desfrutavam de significativos poderes de persuasão, causando sérios riscos ao projeto pombalino. O segundo aspecto está na própria resistência indígena. Embora a documentação nos revele que havia de certa maneira a "persuasão" por parte dos missionários, para além disso, podemos perceber a deserção e a fuga como ações conscientes: a partir do momento em que os índios não estavam satisfeitos com a carga dos serviços que lhes foram propostos, fugiram para outras localidades.

No tocante a esse quadro, uma das dimensões diz respeito ao processo civilizatório que estava relacionado ao projeto pombalino. Nessa compreensão, três pontos são relevantes nesse processo, um deles é o ensino obrigatório da língua portuguesa, o segundo ponto é o casamento entre portugueses e índios, por fim o processo de consolidação do território, mediante a ocupação e da demarcação dos limites das fronteiras lusitanas e espanholas ${ }^{6}$.

Em 1751, Mendonça Furtado encaminhou uma carta ao Vice Provincial da Companhia de Jesus ordenando que, nos trabalhos de catequização e civilização dos índios, os missionários iniciassem o quanto antes o ensino da língua portuguesa com os índios ${ }^{7}$. Na instrução $\S 16^{8}$, a recomendação estava direcionada aos missionários. Quando os índios se dirigiam à administração dos aldeamentos, os religiosos aproveitavam para iniciar o processo de civilização daqueles, uma vez que os índios eram úteis à Coroa. Uma carta enviada pela Coroa lusitana em 1752, à Diogo de Mendonça, secretário de Estado da Marinha e Ultramar, ressalta a instrução $\$ 16$ (conforme apresentada anteriormente). Bem como a resposta que

6 Sobre as Instruções Régias, Públicas e Secretas para Francisco Xavier de Mendonça Furtado, Capitão-General do Estado do Grão-Pará e Maranhão, de 31 de maio de 1751. Ver: Mendonça (2005, tomo I, p. 67-80).

7 Carta de Mendonça Furtado ao Superior vice provincial da Companhia de Jesus, ordenando que o ensino da língua portuguesa, escrita e falada, fosse relacionado a catequese e a civilização dos índios, isso era fundamental para o interesse das capitânias e da Coroa. Ver: AHU. Caixa. 32. Documento. 3063. 18 nov. 1751. p. 01-03.

8 No tocante as instruções. Ver: Mendonça (2005, tomo I, p. 72). 
a Coroa obteve de um dos missionários a respeito do ensino da língua portuguesa aos índios. Nesse caso, o Padre José de Morais, da aldeia Tabapará, próxima à Vila de Vigia, enviou uma carta, ressaltando o trabalho profícuo que estava executando. Embora tal trabalho tenha sido realizado em tão pouco tempo, cerca de um a dois meses, os resultados já estavam aparecendo?.

Além dessa incorporação dos índios por meio do ensino da língua, outro fator que corrobora com essa integração ao projeto metropolitano é a união entre os índios e os colonos portugueses. Em outubro de 1753, uma leva de casais açorianos foi distribuída pelas vilas de Caeté e Bragança, da Capitânia do Estado, para fins de promover o casamento de portugueses com os índios ${ }^{10}$. Entretanto, essa medida desagradou o Bispo do Pará, D. Miguel de Bulhões, que remeteu uma carta ao rei D. José I, informando-o sobre a Lei de 4 de abril de 1755, que autorizava o casamento entre ameríndios e portugueses: era na realidade uma "infâmia" que estava acontecendo ${ }^{11}$.

No tocante a essa questão, nota-se que há uma profunda envergadura das políticas metropolitas em formar casais. Em uma das correspondências, Mendonça Furtado informa ao seu irmão, Marquês de Pombal, que com a introdução de soldados na Vila de Borba é possível certificar-se uma grande possibilidade da formação de casais entre as índias e os soldados (não índios). Deve-se notar que nessa mesma correspondência estava registrado que os casais recebiam uma espécie de dote "presentes", como: fardas, ferramentas e meio alqueire de sal ${ }^{12}$. A fomentação das políticas de casamentos inter-raciais já estava sendo

9 Sobre a civilização por meio da língua portuguesa e a catequese dos índios Sacacas, na llha de Joanes, a documentação ressalta a situação dos jovens indígenas na aldeia e de como estava estabelecido a relação entre eles e os missionários, vinculo este que prevalecia o poder e a submissão dos índios Sacacas. Outra questão que a documentação ressalta, diz respeito ao abandono da aldeia feita pelos missionários após o longo processo que se deu o ensino da língua. Ver: Mendonça (2005, tomo I, p. 227-8).

${ }^{10}$ A possível união matrimonial entre colonos e índios da terra. Ver: AHU. Caixa. 35. Documento. 3251. 11 out. 1753, p. 2-3.

${ }^{11}$ Carta do Bispo Miguel de Bulhões ao rei D. José I, no qual ressalta a publicação do alvará em forma de Lei de 4 de abril de 1755, autorizando o casamento entre portugueses e índias e portuguesas e índios, com a publicação dessa lei, a união entre portugueses e índios deixa de ser "infame", como ressalta a fonte e, passa a ser fundamental por dois motivos, na fixação dos colonos e no povoamento da região. Ver: AHU. Caixa. 38, Documento. 3568. 04 ago. 1755, p. 2.

12 154 a Carta, de 13 de outubro de 1756, no qual Mendonça Furtado ressalta o casamento entre soldados e índias, na Vila de Borba, além disso, o dote que cada casal recebeu, na forma de 
A reorganização e a fluidez do uso da mão de obra indígena no Grão-Pará: segunda metade do século XVIII (1750-1765)

implementada desde 1750. Uma das principais razões dessa política foi a busca incessante de povoar locais estratégicos da Amazônia colonial, além disso, os casamentos serviam para ratificar a demarcação dos limites territoriais, como enfatiza Guzmán (2006).

As demarcações dos limites territoriais na parte norte do vale amazônico eram imprescindíveis para a coroa lusitana. Mas requereu um esforço considerável para pôr em prática. Algumas instruções foram encaminhadas ao Governador do Estado do Grão Pará, Mendonça Furtado, para que tais medidas fossem seguidas ${ }^{13}$. Para esta finalidade, era importante percorrer os mais diversos locais e rios da região e fixá-los aos domínios da Coroa. No tocante ao gerenciamento das funções, era importante nomear um chefe de confiança para comandar as tropas. Tais tropas teriam oficiais militares, astrônomos, geógrafos, capelães, cirurgiões, soldados e gente de serviço: um número considerável de pessoas. Portanto, é perceptível que as demarcações dos limites tinham um contingente expressivo de grupos indígenas a seu serviço, isto fica evidente num ofício encaminhado pelo Provincial do Carmo, padre José da Natividade, para o Diogo Mendonça, o conteúdo do ofício que ressalta a grande quantidade de índios cedidos para as demarcações nos rios Negro e Solimões ${ }^{14}$.

Podemos perceber que as relações entre os agentes coloniais ligados à Coroa lusitana estavam inseridas num quadro múltiplo e que ao mesmo tempo mantinham uma relação dicotômica. Sobretudo o que fica evidente, é a disputa de poder, os conflitos e as negociações. Podemos averiguar também que as relações podem ser de embates, como observamos no caso do padre Júlio Pereira e do índio Manuel, na aldeia Uricuru. Ou entre os índios da Aldeia de Piraviri, no rio Xingu, que reclamavam do missionário e não confiavam no padre João de Souza.

\footnotetext{
"presentes" de Mendonça Furtado, que corresponde ao fardamento que já estava meio desgastado, mas também, camisas e saias de aniagem (tecido de juta), ferramentas (enxada, machado, foice, serrote, enxós e martelo) e terra. Ver: Mendonça (2005, tomo III, p. 162-3).

${ }^{13}$ Para uma discussão mais incisiva sobre os assuntos referentes à "Instrução assinado pela real mão de sua majestade" que diz respeito as demarcações da parte da região norte da Colônia. Ver: Mendonça (2005, tomo I, p. 455-64).

${ }^{14}$ Ofício do provincial do convento do Carmo do Pará, frei José da Natividade, para o secretário de Estado e Ultramar, Diogo Corte Real, sobre os serviços que abarcam a administração das missões, disponibilização de índios para as demarcações e a expedição das Tropas de resgate pelos rios Negro, Solimões e Japorás. Ver: AHU. Caixa. 35. Documento. 3309. 26 nov. 1753. p. 2.
} 
Além disso, podemos ver negociações, como é o caso do padre José da Natividade com Diogo Mendonça, e principalmente, da resistência indígena, quando contingentes de índios fugiam dos serviços prestados à Coroa ou às ordens religiosas.

\section{A LEI DO DIRETÓRIO DOS ÍNDIOS E A INSTABILIDADE DA LIBERDADE INDÍGENA}

Dois anos após a Lei de Liberdade dos índios (1755), outra lei foi instituída, a Lei do Diretório dos Índios (1757), que tinha por objetivo central regular a liberdade indígena. Mas isso não queria dizer que esta lei não abarcasse outros pontos de vista do processo social da Colônia. O Diretório é composto por 95 pontos instrutivos ou parágrafos, dos quais diversos assuntos são tratados. E os conteúdos variam em certa medida, mas possuem pontos em comuns: processo civilizatório, economia, agricultura, comércio e o trabalho indígena (DIRETÓRIO..., 1758). Todos esses pontos culminam numa concordância com as reformas régias.

A ideia não é refletir sobre cada parágrafo que a Lei ressalta, mas sobre pontos pertinentes que nos fazem compreender parte das atividades que giram em torno do trabalho indígena e de como essa mão de obra está inserida num cenário que envolve outros agentes coloniais. É possível vislumbrar na documentação que a mão de obra indígena em alguns casos era remunerada, mas submetida a trabalhos forçados, em outros casos era inexistente o pagamento sobre o trabaIho forçado que os índios executavam. É importante ressaltar também que nem sempre os índios se submetiam aos trabalhos forçados, pois uma das principais formas de reação ou agência indígena que encontramos na documentação foi a fuga, conforme salienta Almeida (2017). Óbvio que existem outras maneiras de se pensar, principalmente, a respeito das estratégias em que os índios se apropriavam para agir em prol de si ou de um grupo, no caso poderia ser o da sua própria etnia.

Sem dúvida que essa política indigenista abrangia outras dimensões do ambiente colonial. Mas a princípio, o objetivo da Coroa portuguesa foi empreender algumas medidas que pudessem assegurar o processo de civilização dos índios e as reformas que estavam sendo implantadas. Uma das instruções que o Diretório ressaltava corresponde à nomeação do Diretor das povoações, que deveria ser feita pelo Governador e Capitão Geral do Estado. Uma das funções desse diretor, dizia respeito ao modo como ele deveria gerenciar e fazer com que as normas 
A reorganização e a fluidez do uso da mão de obra indígena no Grão-Pará: segunda metade do século XVIII (1750-1765)

régias fossem cumpridas em tais povoações (DIRETÓRIO..., 1758, p. 3). Além dos diretores, ainda podemos perceber a presença dos Principais ${ }^{15}$, que foram lideranças indígenas que de alguma maneira conseguiram ser reconhecidas e passaram a ter responsabilidades em cuidar e manter em ordem o funcionamento das vilas, como sublinha Sampaio (2010).

As reformas pombalinas que foram implementadas, em meados do século XVIII, influenciaram relativamente na organização da administração das vilas e povoações da Colônia. Índios passaram a ter papéis importantes no gerenciamento de tais localidades. Esses índios foram designados como Principais, cuja função tinha por intuito de intermediar com as outras autoridades coloniais. Autoridades estas que o Diretório ressalta como os diretores, juízes ordinários, etc. Geralmente os principais eram os porta-vozes da sua vila ou da povoação onde viviam. Essa inserção dos índios na administração colonial, de certo modo fazia parte das reformulações que a metrópole estava executando, tendo em vista que os índios eram fundamentais para consolidar o poderio do império português na região Amazônica, conforme evidencia Melo (2016).

No entendimento da Coroa e mediante a um viés eurocêntrico, a civilização deveria chegar às populações indígenas. Uma das razões estava relacionada ao estado de barbárie e de costumes pagãos que os índios ainda praticavam. Além disso, muitos povos ainda falavam as suas línguas nativas ou a língua geral (Nheengatu), prática que a Coroa portuguesa pretendia extinguir. Para que os índios pudessem sair desse estágio, era importante civilizar, ensinar os mistérios da sagrada religião também ensinar língua portuguesa, assim, ao sair da ignorância e da rusticidade, os indígenas deveriam ser úteis a si, aos moradores e ao Estado. Torná-los súditos ou "cidadãos" portugueses, isso foi um dos objetivos traçados pelas reformas que até então estavam ocorrendo.

${ }^{15} \mathrm{O}$ termo Principal foi atribuído as lideranças indígenas pelos portugueses, no momento do contato, no século XVI. Ver: Cunha (1990); no século XVII, o viajante e ouvidor geral Maurício Heriarte, em 1662, na sua passagem pela região do Pará, Gurupá e Rio Amazonas, descreve o cotidiano de algumas nações indígenas, aos quais manteve relações. Ao navegar pelo rio Tapajó, deparou-se com as nações Marautus, Caguanas e Orucuzos, Heriarte salienta o cotidiano desses grupos indígenas, que comumente estava pautado na caça, pesca e no cultivo de milho, mandioca e na colheita de inúmeras frutas que existiam no local onde estava situada a aldeia. No tocante a liderança desses índios, fazia-se presente a figura do Principal, que tinha autoridade e o respeito pelos demais indígenas, cuidava de cerca de trinta casais. Ver: Heriarte (1874). 
Com esse processo civilizatório, a Coroa portuguesa tinha a pretensão de transformar os índios em súditos através do ensino da língua. O Diretório enfatiza essa perspectiva, pois uma vez estabelecido o aprendizado da língua portuguesa isso permitia a possibilidade da Coroa portuguesa não apenas controlar as fronteiras do território, mas também dominar a própria população local, por isso o ensino obrigatório da "língua do príncipe" efetivaria o projeto pombalino, como acentua Garcia (2007). Nesse sentido, Coelho (2006) sublinha que o ensino da língua foi um instrumento importante nesse contexto para que os planos metropolitanos se consolidassem no território amazônico. É importante refletir que embora essa política causasse um efeito danoso para as populações indígenas, os índios se utilizavam de estratégias para continuar falando o seu idioma. Isto é, os índios de certa maneira não foram submissos aos planos portugueses, mas sim compartilhavam informações entre si, nas suas línguas nativas.

Um claro exemplo a respeito dessa compreensão podemos aferir numa carta de Manoel Francisco, diretor de povoação, encaminhada ao Secretário da Marinha e Ultramar, Manoel Bernardo de Mello e Castro, no qual Francisco ressalta que índios e índias fugiram para os sertões da Capitania ${ }^{16}$. Nesse caso, é possível identificar que esse grupo de índios que comumente eram solicitados nas vilas, acabavam indo trabalhar nas construções das canoas. Trabalho este que demandava de muita força física, que além de construir, deveriam cortar, plainar e conduzir as madeiras aos estaleiros, contudo, isso ocasionava inúmeras fugas para os sertões. Numa outra carta, o diretor da vila de Bragança, Luís Bentes Courat, ressaltava que muitos índios ao serem designados a fazerem as roças dos moradores da vila, acabam fugindo pelos matos ${ }^{17}$. Outro aspecto curioso diz respeito à repartição de índios nas vilas e o quanto é problemática essa questão de distribuir os índios entre as povoações, conforme situa Perrone Moisés (1992, p. 120-1).

\footnotetext{
${ }^{16}$ Arquivo Público do Estado do Pará (APEP). Códice 95. (Acervo Digitalizado). Documento, 0217. 14 maio 1759, p. 133.

${ }^{17}$ APEP. Códice 95. (Acervo Digitalizado). Documentos, 0221-0222. 16 maio 1759, p. 135-6.
} 


\section{REORGANIZAÇÃO DA MÃO DE OBRA INDÍGENA: O OBJETIVO DE TORNÁ-LA MAIS PRODUTIVA PARA A METRÓPOLE}

A mão de obra indígena estava na pauta das políticas da Coroa portuguesa em meados do século XVIII, com a implantação do projeto pombalino, de reorganização da colônia. O trabalho indígena, talvez foi um dos pontos mais importantes e significativos que se verificou no projeto metropolitano. Uma vez que a intenção de reordenação perpassava pela força de trabalho, nesse caso, exercido pela mão de obra indígena.

Foi implantada uma série de medidas que reiteravam a proibição da escravidão indígena, isso se intensifica a partir de 1755. Verifica-se que de certo modo, a mão de obra indígena foi reordenada para fins de suprir as necessidades da Coroa portuguesa e não mais de servir às ordens religiosas. Isto é, a tentativa a todo custo de retirar o monopólio dos missionários sobre o trabalho indígena fez parte desse processo e isso fica evidente. Nota-se também que nesse período a conjuntura política se altera paulatinamente, são perceptíveis as reformas políticas da Coroa portuguesa. Ainda, percebe-se que essa política metropolitana na realidade tinha a intenção de manter o controle dessa mão de obra indígena, para isto, implantou reformas que pudessem reorganizar a sociedade colonial, como evidencia Farage (1986).

Com a implantação da Companhia Geral do Comércio do Grão-Pará e Maranhão, isso ocasionou uma série de alterações no âmbito social e econômico da região. A princípio, um dos motivos dessa implantação foi a possibilidade de retirar o Estado do Grão-Pará e Maranhão da estagnação econômica, mas isso corroborou com outros pontos que estavam interligados a essa questão. Isto é, pontos como na incorporação da mão de obra negra, que seria introduzida na agricultura, nos cortes das madeiras e nos diferentes trabalhos, isso fez com que houvesse a reorganizações tanto na economia da região, na política conforme acentua Dias (1966), como na abolição do poder temporal dos missionários sobre os índios aldeados, de acordo com Farage (1986, p. 21), estes foram aspectos que nortearam as reformas metropolitanas.

No tocante à entrada da mão de obra negra, verifica-se que os africanos escravizados foram inseridos no contexto amazônico no final do século XVII. No entanto, com a intensificação do tráfico africano, houve um aumento considerável 
da mão de obra negra destinada à região amazônica. Isso passou a ocorrer com maior frequência em meados do século XVIII. Uma das razões, foi a implementação da própria Companhia de Comércio que fomentou o tráfico e consequentemente passou a monopolizar o comércio e a rede de distribuição de africanos escravizados para a região, como sublinha Chambouleyron (2006) e Bezerra Neto (2012).

No que diz respeito aos cativos africanos e as relações sociais na Amazônia colonial, observa-se uma relação próxima entre os negros e os índios, mas principalmente na busca das drogas do sertão ${ }^{18}$, no corte de madeiras e nas construções de canoas. É importante ressaltar que os africanos não substituíram de modo algum os índios, isto é, a mão de obra indígena foi tão utilizada quanto a dos africanos. Verificou-se num ofício de 1761, do Governador e Capitão do Estado do GrãoPará e Maranhão, Manuel Castro, encaminhada ao Secretário Mendonça Furtado, a respeito do requerimento dos administradores da Companhia de Comércio, em que houve a solicitação de alguns índios para ensinarem os cativos africanos a cortar madeiras e conduzi-las aos estaleiros. Nessa mesma documentação, nota-se que os índios iam receber certa quantia de réis pelos trabalhos efetuados ${ }^{19}$.

Esta questão evidencia um dado curioso a respeito da mão de obra indígena, sobretudo, no que se refere ao pagamento de uma certa quantia aos índios. Em alguns casos, os índios recebiam em dinheiro pelos serviços prestados. A questão é que muitos índios ainda estavam na condição de escravos. Mesmo com a legislação vigente do Diretório, é possível perceber que a mão de obra indígena foi comumente utilizada nas mais diversas funções, que iam dos cortes de madeiras, extração das drogas até a confecção de tecidos ${ }^{20}$.

Uma das práticas que podemos vislumbrar na documentação se refere a repartição dos índios que acontecia entre os colonos nas mais diversas vilas. Prática esta que foi recorrente na segunda metade do século XVII, de acordo

\footnotetext{
18 No que se refere a essa questão ver: Bezerra Neto (2012).

19 Ofício do Governador e capitão-general do Estado do Pará e Maranhão, Manuel Bernardo de Melo e Castro, para o secretário da Marinha e Ultramar, Mendonça Furtado, no qual Melo e Castro ressalta uma "mudança" de função dos índios, pois ao invés de ficarem retidos nos cortes da madeira, deveriam ensinar aos africanos o manuseio das ferramentas, a forma como se dava os cortes e as árvores que eram mais apropriadas para se fazer canoas, casas e os demais utensílios. Além disso, Melo e Castro reforça a ideia do pagamento diário a esses índios. Ver: AHU. Caixa. 50, Documento. 4607. 3 out. 1761. p. 1-3.

${ }^{20}$ APEP. Códice 95. (Acervo Digitalizado). Documento, 0243. 20 maio 1759, p. 147.
} 
com Mello (2007, p. 208) a predominância da distribuição dessa mão de obra foi feita com certa frequência pelos padres das aldeias. Mesmo com a proibição da escravidão da mão de obra indígena, entretanto, percebe-se que a distribuição de índios não ficava restrita aos colonos, mas essa prática foi algo recorrente entre as autoridades régias.

No tocante a essa questão, o diretor de povoação Cosme Damião, enquanto diretor da Vila de Pombal, repartia os índios para trabalharem nas lavouras e no corte das madeiras, mas também, recebia índios de outras localidades para que pudessem ser distribuídos entre os moradores de Pombal ${ }^{21}$. Essa prática que trata a respeito de repartição dos índios, a priori, tinha como intenção remunerar os índios pelos serviços prestados, mediante as negociações com o empregador, mas ao final do trabalho executado, nem sempre tal empregador cumpria com suas obrigações, além disso, descumpria as normas preestabelecidas, como ressalta Perrone-Moisés (1992, p. 120-1).

Outro caso semelhante ocorreu no remanejamento de alguns índios para os serviços reais. Em um ofício, de meados de 1761, encaminhado ao secretário Mendonça Furtado, do então governador e capitão general Manuel Castro, que ressalta sobre as providências tomadas a respeito dos serviços reais. Está previsto para acontecer de seis em seis meses, posto que esse tempo é necessário para que as povoações não se sintam prejudicadas com a ausência dos índios para os trabalhos. Por esse motivo, adotou-se esse período. Além disso, Castro ressalta que a mão de obra indígena é indispensável para os serviços que se distinguem entre os cortes das madeiras, assim como na sua condução e na construção de embarcações (nau e canoas) e também de charruas (carroças específicas do período) para o Arsenal da cidade 22 .

\footnotetext{
${ }^{21}$ APEP. Códice 95. (Acervo Digitalizado). Documento, 0289. 8 jun. 1759, p. 173.

${ }^{22}$ Ofício do Governador e capitão-general do Estado do Pará e Maranhão, Manuel Bernardo de Melo e Castro, para o secretário da Marinha e Ultramar, Mendonça Furtado. Melo e Castro ressalta em tal documento a necessidade de mais índios para compor o quadro de demandas das embarcações. Ver: AHU. Caixa. 49, Documento. 4514. 22 jun. 1761. p. 1-2.
} 


\section{MOBILIDADES E ARTICULAÇÕES: NUANCES SOBRE AS ESTRATÉGIAS INDÍGENAS}

A mão de obra indígena sempre foi alvo de cobiça entre religiosos, colonos portugueses e até entre as próprias autoridades da Coroa na região amazônica. Mesmo com a promulgação de leis que proibiam o uso do trabalho indígena, sem que houvesse o devido pagamento pelos serviços prestados, no entanto, o uso irrestrito dos índios em diferentes demandas no Estado do Grão-Pará e Maranhão foi algo corriqueiro, principalmente na segunda metade do século XVIII.

A maior parte dos trabalhos desenvolvidos nos diferentes espaços, tais como roças, obras públicas, construções de embarcações, de casas, de igrejas e serviços como guia de viajantes pelos rios da região, era fruto de um considerável contingente de índios. Toda essa complexa rede se situava, em grande medida, nas inúmeras vilas e aldeias que compunham a Capitania do Grão-Pará. Ora, essa perspectiva não soa de forma tão inusitada, tendo em vista que os índios eram imprescindíveis para a formação e o desenvolvimento dessas localidades. Além disso, muitos grupos eram designados para executar os mais diferentes tipos de trabalhos, dos mais "simples" aos mais onerosos que demandavam um grandioso esforço físico.

Em correspondência com o seu irmão, Mendonça Furtado evidencia uma série de fugas indígenas que ocorreram na Capitania, prejudicando assim a continuidade dos serviços régios na região. Na segunda metade do século XVIII, cerca de 65 índios foram trazidos de diferentes aldeias para auxiliar na carpintaria das construções das canoas. Não obstante, os índios foram fugindo paulatinamente. Desses 65 indígenas, sessenta eram da Companhia de Jesus, apenas um índio seria da aldeia dos capuchos e os outros seriam alforriados. Com as fugas em massa, estava instalada a desordem, consequentemente o atraso nas construções das embarcações. Ao solicitar que fossem atrás desses desertores, só trouxeram quinze, os demais já tinham se evadido para outras áreas da região, que de certo modo, eram conhecidas dos próprios índios. Contudo, o caso se agravava ainda mais, quando se descobriu que os mesmos índios que fugiram dos estaleiros da Coroa foram logo empregados nas suas povoações, no serviço dos missionários, construindo-Ihes canoas para serem vendidas às serrarias de madeiras ${ }^{23}$.

${ }_{23}$ 74a Carta, datada de 14 de junho de 1754, em que Mendonça Furtado ressalta, de forma incisiva, 
Mendonça Furtado ressalta que uma das razões destes índios terem fugidos para essas povoações ou aldeias, muito provavelmente, foi porque dificilmente eles seriam castigados pelos moradores e missionários, na realidade esses índios eram protegidos por essas pessoas, tendo em vista que sem os índios, nada se poderia fazer nesses lugares (ver MENDONÇA, 2005, tomo II, p. 177). No tocante a essa questão, isso nos faz refletir a partir de dois fatores: o primeiro diz respeito à dinâmica social em algumas vilas e aldeias; e o segundo, sobre as relações sociais que os moradores e os religiosos tinham com os grupos indígenas nesses espaços, mas é importante pensar que tais relações é algo relativo.

Não eram em todos os espaços que os índios eram comumente subjugados à escravidão e tampouco eram sujeitos a maus tratos, nesse e em outros casos, a negociação ou as alianças se faziam presentes, tendo em vista que os índios eram imprescindiveis em tais localidades. Em alguns casos, os índios tinham a noção que por intermédio do diálogo com esses moradores, poderiam obter algum "ganho". Às vezes, esse "ganho" vinha em forma ora de proteção (o amparo, como Mendonça Furtado ressalta na documentação), ora sem serem infortunados ou obrigados a trabalharem de modo excessivo.

Ao analisar essa correspondência, verifica-se algumas nuances a respeito desse âmbito social. A primeira se refere ao número excessivo de deserções indígenas na produção de canoas. Em segundo lugar, ao analisar o lugar para onde esses índios iam, percebe-se que nem sempre as matas era o principal lugar de refúgio, mas sim povoações ou aldeias que já eram conhecidas pelos próprios índios. Nessas povoações eles eram "bem tratados", pudera, pois, caso fossem submetidos a violências físicas, fugiam ou se rebelavam da mesma maneira que fizeram nos estaleiros. Mas é importante se atentar que supostamente eles só eram "amparados", porque desempenhavam papéis importantes para os moradores locais e eram, sem sombra de dúvida, imprescindíveis para o desenvolvimento da vila ou da aldeia. Por fim, o terceiro ângulo diz respeito à iniciativa dos índios, os quais ao perceberem que em certos locais seriam submetidos a excessivos esforços físicos, violências e abusos, mas em outros espaços poderiam negociar com os religiosos ou moradores, o que achavam melhor para si ou para o grupo no qual estavam inseridos.

a grande quantidade de fugas de índios o que é prejudicial ao andamento dos serviços reais na região. Ver: Mendonça (2005, tomo II, p. 176-8). 
No que diz respeito à evasão indígena, em outro contexto, no início de 1756, Miguel de Bulhões, bispo do Pará, em carta a Mendonça Furtado, vê-se preocupado com as deserções e fugas dos índios que passaram a ser constantes. Com isso, o bispo responsabiliza os moradores e os religiosos pelos atos contra os índios, alegando que aqueles não só não souberam educar estes últimos, como também não corrigiram a prática da deserção por parte dos índios. Sobre isso, encaminhou cartas de ofício ao Prelado da Companhia, da Província da Conceição e da Província da Piedade, solicitando que tomassem providências a respeito dessa desordem que estava acontecendo e pediu para fazer com que os índios evitassem a fuga ${ }^{24}$.

Num outro momento da carta, o bispo é mais enfático ao culpabilizar os moradores pelas suas práticas que, em muitas vezes, eram audaciosas. Visto que na feitoria de cravo, próximo ao rio Moju, Bulhões ressalta que alguns moradores da redondeza e da ribeira do rio capturaram além dos índios que viajavam nas canoas e que iam para Macapá, levaram os índios da própria casa do bispo, da vizinhança e das obras públicas da região. Prática essa que causou sérios problemas ao serviço da Coroa. Um desses moradores foi o Desidério de Sarges que tinha pego esses índios e destinados a feitura de cravos. Ademais, Desidério dissuadiu o índio Mateus da etnia Maracanã, que estava pronto para deslocar-se junto com o Desembargador Ouvidor-Geral a Macapá, dizendo-o para não acompanhar. 0 teor da conversa entre o Desidério e o índio Mateus, não se sabe ao certo, mas no decorrer da viagem, quando o desembargador se deu conta, percebeu que o índio não estava na embarcação que seguia para Macapá (ver MENDONÇA, tomo III, p. 80).

No que se refere ao conteúdo dessa carta, Bulhões está mais preocupado com a utilização da mão de obra dos índios para os serviços da Coroa, do que com os indígenas propriamente dito. Além disso, menciona as fugas e as deserções por causa dos constantes desvios desses índios para outros trabalhos, no caso, a feitura de cravo. Numa outra compreensão que essa mesma correspondência nos revela, refere-se ao entendimento dos índios, isto é, os índios percebendo que ao

${ }^{24}$ Em 30 de janeiro de 1756, o bispo do Pará, Miguel de Bulhões encaminha uma carta ao Governador Mendonça Furtado, na carta o bispo tentar isentar de culpas as ordens religiosas pela frequente incidência de fugas indígenas. Ver: Mendonça (2005, tomo III, p. 78-80). 
se deslocar de uma vila ou aldeia para outra, seria uma excelente oportunidade para fugir, isso era propício porque a fiscalização e o controle ao longo do percurso se mostravam ineficiente sobre eles.

Algo semelhante aconteceu na vila de Beja, onde ficava situada a carvoaria para o cozimento de lenhas. A dita carvoaria era uma das mais relevantes fornecedoras de carvão para as demais aldeias da região. Esse lugar foi um dos principais cenários que abrigava inúmeros grupos de índios que, por sua vez, eram forçados a trabalhar sem nenhum tipo de pagamento. Muitos desses índios eram subjugados a trabalhos excessivos, humilhados e além de tudo isso eram sujeitos a escravidão. Nesse contexto, além das constantes fugas para os sertões, a rebeldia se fez presente, principalmente, nas figuras do índio Antônio Joaquim, juntamente com o preto Zacharias Antônio e um morador da vila de Cametá, ambos acusados de fazerem bulha, isto é, confusão ${ }^{25}$. Nota-se nesse caso, que as fugas não foram as únicas maneiras encontradas pelos índios para se articularem e formularem estratégias para reagirem contra a situação nos quais eram submetidos. Antônio Joaquim, Zacharias Antônio e o outro morador de Cametá, articularam um plano para se rebelar contra os donos da carvoaria que forçavam os índios e as outras pessoas que estavam ali para trabalharem de forma excessiva ${ }^{26}$.

Em outros locais, nota-se uma demanda expressiva do trabalho que era comumente executado pelos índios, ou seja, nas salinas da vila de Sintra a quantidade de índios que trabalhava nesse espaço era significativa ${ }^{27}$. Mas, além dessa vila, na vila de Melgaço, onde cerca de 12 índios foram utilizados em diferentes

25 Observa-se que as sucessivas humilhações na carvoaria na vila de Beja, fez com que o índio Joaquim e o negro Antônio se rebelassem por causa dos maus tratos, a fuga é uma das principais reações, mas quando se trata de fugir para outras regiões, um dos fatores que suscita de imediato na decisão é a possibilidade de se deparar com inúmeros trajetos a ser tomado, pelos rios ou pelas matas, as adversidades ao longo do percurso. Nesse sentido, em determinadas regiões os índios levavam vantagens sobre os negros, visto que eram hábeis e conheciam o território, já os negros ao aventura-se nas matas, não tinham grandes expectativas de ir tão longe por causa da falta dessa familiaridade com a região, isso era um fator que influenciava negativamente no seu deslocamento. Por conseguinte, neste caso, é possível perceber que as razões que levaram tanto Joaquim, como Antônio a fugir para outras localidades (não se sabe ao certo o paradeiro de ambos) se deram pelo fato deles estarem submetidos a sucessivos episódios de violência. Ver: Sampaio (2011).

${ }^{26}$ APEP. Códice 17. Documento, s/n. 26 ago. 1766. s/p.

${ }^{27}$ APEP. Códice 17. Documento, 114. 18 ago. 1766. s/p. 
demandas, trabalhos estes que iam desde o corte de madeiras e sua condução, até no cuidado com as roças, para o sustento dos moradores de tal local ${ }^{28}$. Para tanto, na vila de Sintra, como na de Melgaço aparecem na documentação um número excessivo de fugas e deserções entre os índios. Isto é, muitos acabavam se evadindo para as matas, alguns eram recapturados, mas outros iam para os interiores dos sertões onde dificilmente eram novamente encontrados.

Além dos trabalhos nas roças, carvoarias, estaleiros ou até mesmo nas salinas, o emprego da mão de obra indígena regularmente era utilizado nas obras públicas e privadas. Ou seja, ora os indígenas estavam trabalhando em construções de prédios administrativos (gabinetes, fortalezas, praças e órgãos do governo), ora em prédios religiosos, como igrejas ou conventos, ora nas construções de casas para os moradores das vilas e aldeias. Essa configuração denota uma expressiva circulação da mão de obra indígena, no entanto, o caso se torna mais grave, quando o jornal (pagamento) não era devidamente efetuado aos índios, algo obrigatório pela legislação vigente. Além disso, os trabalhos na construção demandavam um esforço excessivo.

Neste contexto, em uma das cartas ofício, datada de meados de 1759, o Diretor da vila de Soure, Cosme Damião da Silva, destaca que em algumas vezes o tenente José Pedro da Costa, comandante da fortaleza de Gurupá, vem a essa vila para buscar índios para a construção e manutenção dessa fortaleza e também para ir em busca pelas drogas no sertão. Não obstante, no ínterim de uma viagem a outra, o tenente se deparou com deserções em massa dos índios que ele buscava em Soure. Muitos se evadiram para as matas, deixando assim a vila de Gurupá no prejuízo ${ }^{29}$.

Outro enfoque semelhante e que de certo modo nos faz pensar em como os índios estavam inseridos nesse ambiente colonial, diz respeito à vila de São João do Macapá. Onde o diretor da tal vila, Luís da Costa, encaminhou uma carta ao governador Mendonça Furtado. Nesta carta, o diretor faz menção sobre a construção de uma igreja relativamente simples em taipa ${ }^{30}$ com cobertura em palha.

\footnotetext{
${ }^{28}$ APEP. Códice 95. (Acervo Digitalizado). Documentos, 209-212. 13 mai. 1759. pp. 127-130.

${ }^{29}$ APEP. Códice 95. (Acervo Digitalizado). Documentos, 0371-0373. 30 jun. 1759. p. 224-6.

30 Também conhecida como construções de pau a pique, é uma técnica de construção bastante antiga que consiste no entrelaçamento de madeiras tanto na vertical, quanto na horizontal,
} 
Para esta construção, o diretor fez uma lista do que seria preciso para efetuar tal empreitada, além disso, ressalta que seriam necessários cerca de 54 índios, os quais foram divididos em diferentes tarefas. As tarefas estavam divididas em serrar madeiras, alguns índios vieram da vila Santa Anna para executar tal função, no entanto, no caminho, muitos morreram em razão das doenças que eles foram acometidos, outros acabaram fugindo para as matas. Ademais, alguns índios foram encaminhados para realizarem a tiragem do barro que ia ser destinado a olaria, outros para retirada de pedras, uma certa quantidade para auxiliar na pescaria e na caça, outros no pastoreio dos bois ${ }^{31}$.

É possível vislumbrar por meio desses documentos que os índios estavam diretamente incorporados na prática dos ofícios diários, de mando e desmando. Em certos momentos, a situação pendia para o lado mais danoso para a população indígena, mas era possível verificar que em várias situações nos deparamos com os índios se articulando e se mobilizando para contornar a submissão que Ihes eram impostas. Uma das principais ações que as fontes históricas sugerem diz respeito às deserções e fugas em massas para os sertões. Mas além disso, muitos índios buscavam se rearticular com outros grupos indígenas para resistir a dominação colonial, outros acabavam buscando os seus direitos legais, pois sabiam que a escravidão e o contrabando de índios eram proibidos pela Lei do Diretório dos Índios. No que abarca essa questão, as cafuzas Rita e Sizília entraram com um requerimento junto ao órgão responsável do governo, solicitando o reconhecimento da liberdade de ambas ${ }^{32}$.

\section{OS ÍNDIOS COMO SUJEITOS HISTÓRICOS NO CONTEXTO AMAZÔNICO}

Quase uma década após a promulgação das leis que abarcavam a regulação da liberdade indígena, foi possível apurar uma significativa diversidade da inserção desses índios em diferentes espaços. Onde havia a predominância da mobilidade e da ação indígena, mas também, das estratégias, negociações e alianças, entretanto, nota-se a sujeição ao cativeiro, de trabalhos forçados, de abusos e violências

cuja fixação é feita no solo. As madeiras são amarradas entre si por cipós e em seguida são preenchidas com solo argiloso, geralmente o barro.

${ }^{31}$ Arquivo Público do Estado do Pará (APEP). Códice 98, Documentos, 040-046. 12 jan. 1759. p. 55-67.

32 Arquivo Histórico Ultramarino (AHU). Caixa 50, Documento, 4605. 22 set. 1761. p. 1-4. 
constantes. Tudo isso estava relacionado mediante a uma situação social, na qual os grupos indígenas se faziam presentes como agentes históricos, isto é, eram sujeitos que desenvolviam papéis de suma relevância nesse cenário colonial.

É importante ficar atento para não cair em certas armadilhas e não se deixar levar por algumas situações ou por certos contextos, porque em alguns casos, a tendência é pensar que os índios comungavam com as mais diversas formas de submissão de maneira pacífica e sem que houvesse qualquer tipo de ação contrária. Como podemos perceber até aqui, cuja ênfase foi dada de modo contundente sobre as estratégias e ações indígenas, constatou-se que os índios realizavam práticas, ora de maneira individual, ora de forma coletiva, como destaca Monteiro (1999). Nesse sentindo, é importante refletir sobre essas nuances, isto é, de que forma os grupos indígenas atuavam nesse contexto colonial?

Ao analisar as fontes históricas referentes ao assunto indígena, foi possível compreender as diferentes formas em que se davam as ações dos índios. As mais comuns foram as evasões para as matas, além das negociações e das as alianças que comumente os índios faziam. Outro aspecto que também refletia a atividade indígena foi o embate, por meio dos qual os índios lutavam em prol de si ou de grupos étnicos. Mas, não é de modo geral que essas ações se mostravam de maneira clara, muitas dessas atuações se apresentavam de forma "velada" ou "sutil".

A questão neste caso é que nem sempre a documentação nos revela esse tipo de ação sutil dos índios, um exemplo disso, foi a atitude do índio Mateus da etnia Maracanã que se evadiu da embarcação que ia de viagem a Macapá, um ato sem grande expressão, mas que denota o quão o dito índio poderia decidir a respeito de certas circunstâncias. Outro caso que já foi ilustrado no primeiro capítulo, refere-se ao índio Manuel, da aldeia de Uricuru, que solicitou à secretária de Estado a autorização para viver em uma outra aldeia em localidades próximas à Uricuru, pois tinha o intuito de viver a "seu gosto". No entanto, o requerimento do índio Manuel causou uma certa fúria do Pe. Júlio Pereira, no qual era o religioso responsável da aldeia de Uricuru ${ }^{33}$.

\footnotetext{
33 1a Carta, de 21 de novembro de 1751, de Mendonça Furtado ao seu irmão Marquês de Pombal, em que ele trata sobre os limites das fronteiras do Estado, das ordens religiosas e de como o trabalho dos religiosos tem influenciado as populações indígenas. Ver: Mendonça (2005, tomo I, p. 109-26).
} 
Nesse processo, outro exemplo que reforça a ideia de que os índios não se sujeitavam pacificamente a qualquer dominação, diz respeito às ações que foi vista do índio Antônio Joaquim que se rebelou na carvoaria na vila de Beja, onde ele não concordava com os maus tratos e as constantes violências que ali existiam. Ademais, um dos principais meios que os índios encontraram para tirar "proveito" de alguma situação foi a evasão para os sertões ${ }^{34}$ que, de certo modo, foi um dos meios encontrados para deixar aquela realidade de sujeição. Conforme Coelho (2008, p. 277) as guerras era um dos meios que os índios encontravam para agir, um exemplo disso foi o assassinato, em 1766, da autoridade colonial Francisco Rodrigues, durante a tentativa de descimento dos índios Mobiú.

A legislação ou os recursos legais também serviram como "amparo" para que os índios se livrassem da condição de escravos. Nesse caso, os índios recorriam às autoridades responsáveis mediante aos instrumentos legais, que geralmente eram por meio de queixas, requerimentos e petições com a finalidade de alegar que eram livres e que por lei não poderiam ser submetidos à escravidão, como sublinha Domingues (2000, p. 269-70). Outra maneira que os índios encontraram para agir foi mediante ao uso da língua indígena. Muito embora fosse proibido o uso das línguas maternas em diversas vilas ou aldeias, muitos grupos ainda se comunicavam "discretamente" na sua língua mãe, de modo que os segredos ou expressões que tinham uma certa importância na conversa fossem ocultados dos brancos, como aponta Garcia, (2007).

Na concepção de alguns colonizadores, o principal motivo que levava os índios a desertarem os trabalhos na vila era a falta de hábito em relação trabaIho intenso. Sobre essa questão, os colonos compreendiam que os índios eram indivíduos preguiçosos e desprovidos de um propósito maior, como ressalta o

\footnotetext{
${ }^{34} \mathrm{Na}$ prática, os estabelecimentos de mocambos em algumas regiões dos sertões amazônicos foram comuns e, principalmente, serviram como espaços de interação entre negros e índios fugidos, a localização desses núcleos geralmente variavam, mas a incidência desses espaços, naquele período, verifica-se em regiões como Cametá, Moju (vilas de São Miguel e Almas), vilas próximas ao rio Tapajós, vila do Conde e Piriá até áreas mais distantes como a fronteira das Guianas. Esses lugares serviram como rotas de fugas e pontos específicos de acolhimento de negros e índios que ao se sentirem seguros acabavam permanecendo e fundando outros núcleos próximos da região, entretanto, quando o perigo ainda estava à espreita, havia duas possibilidades, continuar fugindo até encontrar um local mais seguro, ou entregar-se e sofre severas punições, levando a morte, em alguns casos. Ver: Gomes (2011) e Gomes e Marin (2003).
} 
governador João Pereira Caldas, acentuando a falta de ambição dos grupos indígenas $^{35}$. Na realidade, antes deles serem trazidos, mediante as capturas ou dos descimentos às vilas ou aldeias, muitos desses povos indígenas já viviam a sua própria rotina no interior dos sertões amazônicos. A predominância da caça, da pesca, da coleta de frutas e de outras especiarias para a subsistência do grupo fazia parte dessa complexa conjuntura. Contudo, as demandas de serviços que exigiam um acentuado esforço eram bem menores do que, por exemplo, o trabalho em uma carvoaria ou num estaleiro.

Ainda nesse raciocínio, o cronista e padre jesuíta João Daniel, ressalta algo semelhante, entretanto, do mesmo jeito que ele enfatiza a habilidade e a aptidão dos índios, posto que exerciam com afinco os diferentes tipos de ofícios, sobretudo, a carpintaria. O padre acentua o primor dos índios na execução de trabalhos que tinham como principal matéria prima, a madeira, isto é, eram hábeis na carpintaria. No colégio dos padres jesuítas na cidade de Belém, os índios confeccionaram além das imagens em madeira de dois anjos tocheiros (imagens estas que tinham a finalidade de comportar velas), também fizeram com certa maestria os púlpitos do altar mor da capela. Não obstante, apesar de toda essa competência que o padre ilustra sobre os índios, ele é bastante enfático ao mencionar que os índios eram comumente acometidos por uma profunda preguiça, um vício que os acompanhavam constantemente, conforme sublinham autores como o padre e cronista jesuíta Daniel (2004) e Guzmán (2015).

No que se refere a essas concepções, é possível destacar algumas nuances a respeito do ponto de vista de alguns sujeitos históricos, como a do governado João Caldas e a do cronista e padre João Daniel. Ambos, estavam inseridos no exercício sistêmico de funções, nas quais a predominância da rigidez e da jornada

\footnotetext{
${ }^{35}$ Carta, de 25 de maio de 1757, endereçada ao Governador da Capitania do Maranhão, cujo teor da correspondência ressalta a aplicabilidade do Diretório, mas principalmente a respeito da preguiça e indisposição dos índios. Ver: Mendonça (2005, tomo III, p. 271-2); Carta a Tomé J. da C. Corte Real, cujo conteúdo se refere a situação da Capitania, da Lei de Liberdade dos Índios (1755), além disso, ressalta a aversão aos trabalhos por causa da preguiça. Ver: Mendonça (2005, tomo III, p. 292-96); Ofício do Governador e capitão general do Estado do Pará e Rio Negro, João Pereira Caldas, para o secretário de Estado da Marinha e Ultramar, Martinho de Melo e Castro, a respeito dos intendentes do comércio em visitas às povoações dos índios no Pará e no Rio Negro, para fins de verificarem as atividades agrícolas e comerciais nessas povoações. As informações que Caldas recebeu dos intendentes e que ele enfatiza no ofício, referem-se a como os índios eram tomados pela fadiga e preguiça. Ver: AHU. Caixa 74, Documento. 6249. 06 nov. 1775.
} 
diária dos ofícios eram exaustivas, mas ao se depararem com o modo ou o estilo de vida que os índios levavam, estranharam aquelas práticas, julgando-os como preguiçosos, desprovidos de qualquer ambição ou avessos aos trabalhos. Nesse sentido, de acordo com Henrique (2010), é importante ressaltar que os povos indígenas tinham à sua maneira de viver, a sua dinâmica de trabalhar, cuja predominância de horários rígidos nem sempre seguiam o padrão nos quais os brancos ou os europeus estavam habituados.

\section{CONSIDERAÇÕES FINAIS}

Durante o percurso deste trabalho, empreendeu-se de modo salutar, uma busca incessante para compreender as relações que abarcavam a dimensão social da Capitania do Grão-Pará, onde os agentes coloniais que pudemos averiguar se relacionavam na região amazônica. Desde o princípio, a pretensão foi situar o leitor no contexto histórico do período estudado, para que posteriormente a reflexão pudesse avançar no que diz respeito aos enfoques relacionados ao protagonismo indígena.

É perceptível que a inclinação feita, visou compreender não somente as noções relacionadas a política, a economia e a compreensão jurídica da sociedade, mas buscou-se analisar e evidenciar uma rede de relações sociais entre colonos portugueses, missionários das ordens religiosas, autoridades coloniais juntamente com os grupos indígenas. No entanto, quais eram as características que norteavam essas relações? Quais eram os tipos de sujeições que incidiam diretamente nos grupos indígenas? De que formas os índios se articulavam e passaram a criar mecanismos para contrariar as inúmeras formas de subordinação?

Essas e outras questões serviram como arcabouço para elucidar certos meandros, principalmente a respeito da implantação das leis que tinham por objetivo a promoção da liberdade dos índios, como ressalta a Lei do Diretório dos Índios, promulgada em 1757. Entretanto, nesse contexto verifica-se que a mão de obra indígena além dela está inserida num processo que visava a sua reorganização, em razão das políticas metropolitanas, os índios ainda eram comumente cobiçados pelos moradores, pelas autoridades coloniais e pelos missionários, ocasionando assim a escravidão indígena como algo frequente nos recônditos amazônicos. 


\section{REFERÊNCIAS}

ALMEIDA, Maria Regina Celestino de. A atuação dos indígenas na história do Brasil: revisões historiográficas. Revista Brasileira de História, São Paulo, v. 37, n. 75, p. 17-38, 2017.

BEZERRA NETO, José Maia. A 'rota negra' entre o Grão-Pará e a África: um mar de incertezas e muitas histórias. In: BEZERRA NETO, José Maia. Escravidão negra no Pará (séculos XVII -XIX). 2. ed. Belém, PA: Paka-Tatu, 2012. p. 25-69.

CHAMBOULEYRON, Rafael. Escravos do Atlântico equatorial: tráfico negreiro para o Estado do Maranhão e Pará (século XVII e início do século XVIII). Revista Brasileira de História, São Paulo, v. 26, n. 52, p. 79-114, 2006.

COELHO, Geraldo Mártires. Estratégias civilizacionais: língua e poder na Amazônia pombalina. Anais do Arquivo Público do Pará, Belém, v. 5, t. 1, p. 125-38, 2006.

COELHO, Mauro Cezar. O Imenso Portugal: vilas e lugares no Vale Amazônico. Territórios e Fronteiras, Cuiabá, MT, v. 1, n. 1, p. 263-83, jan./jun. 2008. (Dossiê Temático: Império Português-Brasileiro-Espanhol I).

COELHO, Mauro Cezar. A construção de uma lei: o Diretório dos Índios. Revista IHGB, Rio de Janeiro, ano 168, n. 437, p. 29-48, out./dez. 2007.

CUNHA, Manuela Carneiro da. Imagens de índios do Brasil: o século XVI. Estudos Avançados, São Paulo, v. 4, n. 10, p. 91-110, set./dez. 1990.

DANIEL, João. Da grande habilidade e aptidão dos índios. In: DANIEL, João. Tesouro descoberto no máximo rio Amazonas. Rio de Janeiro: Contraponto, 2004. v. 1, p. 341-3.

DIAS, Manuel Nunes. Fomento Ultramarino e Mercantilismo: a companhia geral do GrãoPará e Maranhão (1755-1778). Revista de História, São Paulo, v. 32, n. 66, p. 359-71, jun. 1966. Disponível em: http://www.revistas.usp.br/revhistoria/article/view/124426. Acesso em: 22 maio 2018.

DIRETÓRIO que se deve observar nas povoações dos índios do Pará, e Maranhão enquanto sua Majestade não mandar o contrário. Biblioteca Digital da Câmara dos Deputados, 1758.

DOMINGUES, Ângela. Quando os índios eram vassalos: colonização e relações de poder no Norte do Brasil na segunda metade do século XVIII. Lisboa: Comissão Nacional para as Comemorações dos Descobrimentos Portugueses - CNCDP, 2000. 
A reorganização e a fluidez do uso da mão de obra indígena no Grão-Pará: segunda metade do século XVIII (1750-1765)

FARAGE, Nádia. As muralhas dos sertões: os povos indígenas no rio Branco e a colonização. Rio de Janeiro: Paz e Terra/Anpocs, 1991.

FARAGE, Nádia. A política indigenista pombalina na Amazônia: algumas considerações. Comunicação apresentada ao GT. História Indígena e do Indigenismo. In: ENCONTRO DA ANPOCS, 10., out. 1986. p. 20-47.

GARCIA, Elisa Frühauf. O projeto pombalino de imposição da língua portuguesa aos índios e a sua aplicação na América meridional. Tempo, Niterói, RJ, v. 12, n. 23, p. 23-38, 2007. Disponível em: http://www.scielo.br/scielo.php?script=sci_arttext\&pid=S141377042007000200003\&lng=en\&nrm= iso. Acesso em: 11 mar. 2018.

GOMES, Flávio. Migrações, populações indígenas e etno-genese na América Portuguesa (Amazônia Colonial, s. XVIII). Nuevo Mundo Mundos Nuevos, 2011, Disponível em: http:// journals.openedition.org/nuevomundo/60721. Acesso em: 15 ago. 2018.

GOMES, Flávio; MARIN, Rosa Elizabeth Acevedo. Reconfigurações coloniais: tráfico de indígenas, fugitivos e fronteiras no Grão-Pará e Guiana Francesa (Séculos XVII e XVIII). Revista de História, São Paulo, n. 149, p. 69-107, 2osem. 2003.

GUZMÁN, Décio de Alencar. Festa, preguiça e matulagem: o trabalho indígena e as oficinas de pintura e escultura no Grão-Pará, sécs. XVII-XVIII. Revista Estudos Amazônicos, v. XIII, n. 1, p. 1-29, 2015. (Dossiê: História Indígena ).

GUZMÁN, Décio de Alencar. Índios misturados, caboclos e curibocas: análise histórica de um processo de mestiçagem, Rio Negro (Brasil, séculos XVIII e XIX). In: ADAMS, C.; MURRIETA, R.; NEVES, W. (Org.). Sociedades caboclas amazônicas: modernidade e invisibilidade. São Paulo: Annablume, 2006. p. 67-80.

HENRIQUE, Márcio Couto. Conceitos e preconceitos em história indígena. In: COELHO, Wilma de Nazaré Baia; MAGALHÃES, Ana Del Tabor Vasconcelos (Org.). Educação para a diversidade: olhares sobre a educação para as relações étnico-raciais. Belo Horizonte: Mazza Edições, 2010. p. 79-95.

HERIARTE, Mauricio de. Descrição do estado do Maranhão, Pará, Corupá e Rio das Amazonas. Vienna d'Austria: Imprensa do filho de Carlos Gerold, 1874. p. 36-8. Disponível em: http://objdigital.bn.br/acervo_digital/div_obrasraras/or110374/or110374.pdf. Acesso em: 18 ago. 2018.

MAXWELL, Kenneth. Reforma. In: MAXWELL, Kenneth. Marquês de Pombal: paradoxo do Iluminismo. Rio de Janeiro: Paz e Terra, 1996. p. 96-117. 
MELLO, Márcia Eliane Alves de Souza. Fé e Império: as Juntas das Missões nas conquistas portuguesas. Manaus: EDUA- Editora da Universidade Federal do Amazonas, 2007.

MELO, Vinícius Zúniga. Os diretores de povoações: serviços e transgressões no GrãoPará do diretório dos índios (1757-1798). 2016. 201 f. Orientador: Mauro Cesar Coelho Dissertação (Mestrado em História Social) - Instituto de Filosofia e Ciências Humanas, Programa de Pós-Graduação em História Social da Amazônia, Universidade Federal do Pará, Belém, 2016.

MENDONÇA, Marcos Carneiro. A Amazônia na Era Pombalina: correspondência inédita do Governador Capitão-General do Estado do Grão-Pará e Maranhão Francisco de Xavier de Mendonça Furtado (1751-1759). 1. ed. Brasília: Senado Federal, 2005. Tomos I, II e III.

MONTEIRO, John M. Armas e armadilhas: História e resistência dos índios. In: NOVAES, Adauto (Org.). A outra margem do Ocidente. São Paulo: Companhia das Letras, 1999. p. 237-49.

PERRONE-MOISÉS, Beatriz. Índios livres e índios escravos: os princípios da legislação indigenista do período colonial, séculos XVI a XVIII. In: CUNHA, Manuela Carneiro da (Org.). História dos índios no Brasil. São Paulo: Companhia das Letras, 1992. p. 115-32.

SAMPAIO, Patricia Melo. Escravos e escravidão africana na Amazônia. In: SAMPAIO, Patricia Melo (Org.). O fim do silêncio: presença negra na Amazônia. Belém, PA: Editora Açaí/CNPq, 2011. p. 14-42.

SAMPAIO, Patrícia Melo. Índios e brancos na Amazônia Portuguesa: políticas e identidade no século XVIII. In: CHAMBOULEYRON, Rafael; ALONSO, José Luis Ruiz-Peinado (Org.). T(r) ópricos de história: gente, espaço e tempo na Amazônia (séculos XVII A XXI). Belém, PA: Editora Açaí/Programa de Pós-graduação em História Social da Amazônia (UFPA)/Centro de Memória da Amazônia (UFPA), 2010. p. 99-116.

VILLALTA, Luiz Carlos. Reformismo ilustrado, censura e práticas de leitura: usos do livro na América Portuguesa. 1999. Orientadora: Laura de Mello e Souza. Tese (Doutorado em História Social)- Faculdade de Filosofia, Letras e Ciências Humanas, Universidade de São Paulo, São Paulo, 1999.

\section{Fontes Documentais}

Arquivo Histórico Ultramarino

Caixa 32. Documento. 3063. 18 nov. 1751. p. 01-03.

Caixa 35. Documento 3251. 11 out. 1753, p. 2-3.

Caixa 35. Documento 3309. 26 nov. 1753. p. 2. 
Caixa 38. Documento 3568. 4 ago. 1755, p. 2.

Caixa 49. Documento 4514. 22 jun. 1761. p. 1-2.

Caixa 50. Documento 4605. 22 set. 1761. p. 1-4.

Caixa 50. Documento 4607. 3 out. 1761. p. 1-3.

Caixa 74. Documento 6249. 6 nov. 1775.

Arquivo Público do Estado do Pará

Códice 17. Documento 114. 18 ago. 1766. s/p.

Códice 17. Documento s/n. 26 ago. 1766. s/p.

Códice 95. (Acervo Digitalizado). Documento 0217. 14 maio 1759. p. 133.

Códice 95. (Acervo Digitalizado). Documento 0243. 20 maio 1759. p. 147.

Códice 95. (Acervo Digitalizado). Documento 0289. 8 jun. 1759, p. 173.

Códice 95. (Acervo Digitalizado). Documentos 0221-0222. 16 mai. 1759. p. 135-36.

Códice 95. (Acervo Digitalizado). Documentos 0371-0373. 30 jun. 1759. p. 224-6

Códice 95. (Acervo Digitalizado). Documentos, 209-212. 13 mai. 1759. p. 127-30.

Códice 98. Documentos 040-046. 12 jan. 1759. p. 55-67.

\section{Sobre os autores:}

Décio de Alencar Guzmán - Mestrado em História pela Universidade Estadual de Campinas (UNICAMP). Especialização e graduação em História pela Universidade Federal do Pará (UFPA). Professor Adjunto da UFPA. Tem experiência na área de História, com ênfase em História do Brasil Colônia, História Indígena e do Indigenismo e História da Amazônia. Publicou livros, capítulos de livros e artigos no Brasil, Bélgica, Estados Unidos, França, Itália, México e Peru. E-mail: decioguz@ufpa.br

Leonardo Raiol Junior - Graduado em Licenciatura em História pela Universidade Federal do Pará. Membro do Grupo de Pesquisa de História Indígena e do Indigenismo- GP HINDIA. Professor de História da América da Rede Emancipa: Movimento Social de Educação Popular. Foco de pesquisa, mão de obra indígena, com ênfase nos estudos a partir da segunda metade do século XVIII (1750-1780).

E-mail: Irj.raiol@gmail.com

Recebido em 15 de setembro de 2018

Aprovado para publicação em 13 de março de 2018 
